\title{
Study on the Accounting of Enterprise Pension under the Background of Aging
}

\author{
Liu Lin ${ }^{1}$, Li Xinhua ${ }^{2}$ \\ ${ }^{1}$ Haikou University of Economics, Hainan Haikou, 71127 \\ ${ }^{2}$ Hainan College of Economics and Business, Hainan Haikou, 71127
}

Keywords: the background of aging; enterprise pension; accounting problems

\begin{abstract}
With the development of medical science and technology, the decline of human birth rate and death rate, the age of global population aging has gradually come into being, the problem of pensions under the background of aging has attracted more and more people's attention, and the pension system in various countries is facing different degree of difficulty. Although China has gradually established a multi-level pension insurance system, there are still many deficiencies in the enterprise pension accounting system, which poses a hidden danger to social stability. This paper analyzes the problems existing in the enterprise pension accounting, and puts forward the reform countermeasures to promote the improvement of the accounting of the enterprise pension under the background of aging.
\end{abstract}

\section{Introduction}

China has officially entered an aging society since 2000. How to do well in social security, to create an effective pension system has become a major livelihood problem in China, and its research is ongoing. Under the background of aging, the pension system is confronted with enormous challenge, the basic pension expenditure expands rapidly, and the government is in financial predicament. In order to get rid of the tide and strengthen the research on the pension problem, it is imperative to study the accounting problem of enterprise pension, so as to promote the reform and development of the pension system [1].

\section{Enterprise Pension Concept}

Enterprise pensions are usually paid by the Government, enterprises, financial institutions, etc., which is a pension that can be acquired by the employees after they meet the requirement of their working life or after they have been divorced from work. It is usually paid monthly. At present, the understanding of the nature of pension can be divided into social welfare view and labor remuneration view. The concept of social welfare is to take the pension as a kind of welfare, let the enterprise staff feel at ease in long-term work and receive the pension after retirement, which fully embodies the enterprise and the government's humanistic care. The view of labor remuneration is to treat the pension as another remuneration due during the work of the employee. After retirement, it will be refunded. Under this concept, the pension accounting system must be perfected, and the pension payment obligation of retired workers should be measured [2].

\section{The Problem of Enterprise Pension Accounting under the Background of Aging}

Enterprise pension accounting was first formed in western countries, and gradually perfected with scientific theoretical system, which can provide the guidance of system theory for pension accounting activities and ensure the smooth carrying out of pension accounting activities. However, compared with western developed countries, China's pension accounting system started late and develops slowly. It is still in the process of continuous exploration in order to combine our national conditions to create a theory system of pension system. However, as far as the present stage is concerned, there is a lack of sound theoretical basis and practical activities, there is still no sound corporate pension accounting system, and the pension accounting is not perfect. Therefore, in the 
absence of systematic theoretical guidance and aging background, there are many problems in the process of enterprise pension accounting, and the formulation of corresponding accounting standards is hindered [3].

With the advent of an aging society, our country is constantly improving the pension accounting system, and the current accounting standards are revised and improved. For example, in the Enterprise Accounting Standards 9th-Staff Compensation, "post treatment" has been added, and the after-service welfare treatment has been clarified and supplemented, which clearly defined the pension deposit as well as income plan, specify the detailed provision of pension measurement, confirmation, information disclosure, and match the current market economy development, fully embodying the protection of the legitimate rights and interests of workers. However, the study of the theory of after-service welfare accounting is still not perfect, there are few practical activities, and many provisions in the guideline are not entirely appropriate, such as simple rules of income plan, no quantitative data of information disclosure, etc. Under the aging background, the enterprise pension expenditure will inevitably increase, the corresponding provisions are not clear, and information disclosure is unsound, which will affect the decision-making of enterprises, as well as the overall development of enterprises [4].

In the operation process of pension accounting, the endowment insurance system is the most important external environment. At present, the level of endowment insurance in our country embodies diversification, but the system is still imperfect, which leads to the defects of the system environment of pension accounting operation. The implementation of the "unification" of pensions has led to increased costs. After the unification, more than 40 million of the public service units need to pay $20 \%$ of the basic endowment insurance and $8 \%$ of the occupational pension, which undoubtedly increases the unit's expenditure and bring a great deal of resistance for the implementation of the unification scheme. Therefore, in order to ensure the implementation of the pension scheme, we must first solve the problem of the unit cost increase. In addition, the development of enterprise annuity in China is not sufficient. In the enterprises with the enterprise annuity system, the employee who joins the enterprise annuity plan only occupies $2.5 \%$ of the national basic endowment insurance amount. The enterprise annuity base is weak, and the coverage scope is small. Besides, the endowment insurance system in China also has a gap and a low yield. It is these external institutional environmental deficiencies hinder the development of pension accounting [5].

In the Enterprise Accounting Standards $9^{\text {th }}$, a revenue plan has been set up. The implementation of the plan mainly includes two aspects: first, the actuary conducts the actuarial assumptions according to the operation of the enterprise, on the basis of which the specific detailed report can be obtained; second, accounting personnel conducts accounting treatment according to actuarial reports. Therefore, the overall planning process requires the cooperation of accountants and actuaries, so as to ensure the accuracy of actuarial reports and the quality of accounting. However, the development of China's insurance industry is slow, the number of actuaries is small, and the actuarial strength is scarce, so it is unable to provide sufficient actuarial strength support for pension accounting, which affects the quality of accounting [6].

\section{Countermeasures of Perfecting Enterprise Pension Accounting under the Background of Aging}

In order to perfect the enterprise pension accounting, it is necessary to improve the theory of enterprise pension accounting from the perspective of enterprise pension accounting objectives and accounting information quality characteristics. The accounting target of pension has gradually formed two viewpoints: one is the effective view of decision and the other is the concept of fiduciary duty. The accounting standards promulgated in our country take into account the validity of the decision on the basis of the concept of fiduciary duty, that is, to run the relevant accounting information for the open enterprise, to reflect the performance of the entrusted responsibility by the enterprise managers, and to facilitate the effective decision-making of the external information users [7]. In the rapid development of market economy and under the aging background, enterprises 
have a strong awareness of the rights of workers, and the need for pension information is particularly strong. Therefore, the effectiveness of pension accounting information must be guaranteed. We should make reference to the practice of international peers and set up specific pension accounting objectives according to market situation, stipulate the provision of enterprise pension costs, assets, liabilities and other information, so as to facilitate effective decision-making by stakeholders, and truly reflect the performance of the enterprise's responsibility for the old-age security.

The characteristics of accounting information quality should include: the correlation and authenticity characteristics of information quality, comparability of information quality, verifiable, understandable, timeliness and other strengthening features. In the accounting standards of our country, we also put forward the corresponding characteristics of accounting information quality, including the reliability and relativity determined by the concept of fiduciary duty. Therefore, the change of accounting target will also lead to different quality characteristics of accounting information. In combination with the characteristics of pension, the quality of accounting information should conform to the characteristics of correlation, and guarantee the reliability of information in the case of relevant stakeholders.

The practical application of perfecting the enterprise pension accounting should be based on perfecting the confirmation of the enterprise pension, the measurement of the enterprise pension accounting and the disclosure of the pension accounting information. The recognition of pension is the basis, and the obligation that enterprises should fulfill. This is also consistent with the principle of accrual basis, and it should be based on the recognition of the accounting for the pension system. In addition, additional accounting subjects should be set, and appropriate additional accounts should be added to reflect pension payments and status. On the basis of the original account system, we should increase the pension payable and budget pension, or combine with the actual situation of enterprises to establish a separate pension account system [8].

The measurement of enterprise pension accounting is the most important. In the Enterprise Accounting Standards $9^{\text {th }}$, it also makes special provisions that enterprises should choose fair value to measure pension assets, to ensure the effective implementation of pension plans. But at present, the practical experience of choosing fair value measurement is extremely lack, and there are some obstacles to the smooth operation of pension accounting. To solve this problem, we should strengthen the theoretical research on fair value, perfect the theoretical system, improve the comprehensive quality of accounting practitioners, and accurately judge the fair value.

The disclosure of pension accounting information can take two kinds of models. One is to increase the current backbone of the disclosure of pension accounting in the existing financial statements, to increase the pension plan assets in the balance sheet, to increase the pensions payable in the field of liabilities, etc. The second is to disclose the pension accounting separately in the government-mandated website.

In the solution of pension unification scheme, the problem of huge transition cost can be referred to other countries ' practice by means of nominal account. At the same time, the relevant government departments should strengthen the existing financial expenditure structure adjustment and increase social insurance financial investment. In addition, institutions should continue to streamline the structure, reduce unnecessary expenditure and the number of workers, and cut the consumption of human resources. Besides, the Government should strengthen the promotion of tax preferential policies, solve the problem of low coverage of enterprise annuity, and reduce the burden of personal tax on annuity by implementing the preferential policies of individual income taxation of enterprise annuity. Through the above solutions, the enterprise pension accounting operation of the external links should be improved to avoid the formation of defects.

\section{Conclusion}

In short, with the advent of an aging society, the pension system in various countries have ushered in a great challenge. It has become an important issue for people's livelihood to study the pension accounting problems and improve the pension system. Comparatively speaking, our 
country's enterprise pension accounting starts late, the theory system and practice system are not perfect, and the operation of enterprise pension accounting has many problems. China should strengthen the standard of pension accounting to make it adapt to the development of market economy better.

\section{References}

[1] Yang Peiyi. Discussion on Accounting Problems of Enterprise Pension in China [J]. Knowledge Economy, 2017, 13 (17): 84+86.

[2] Huang Bowei. Study on Accounting Problems of Enterprise Pension in China [J]. Management Observations, 2016, 14 (20): 147-149.

[3] Zhou Xiaojuan. Study on Accounting Problems of Enterprise Pension in China [J]. Accounting for Township Enterprises in China, 2016, 10 (06): 12-13.

[4] Li Tingting. Study on the Accounting of Enterprise Pension in China [D]. Liaoning University, 2016.

[5] Zhang Weiwei. Accounting Problems and Strategies of Enterprise Pension in China [J]. China Market, 2015, 11 (12): 45-46.

[6] Cao Jian. Study on the Accounting of Enterprise Pension in China [D]. Shanxi University of Finance and Economics, 2015.

[7] Fu Min. Study on Accounting Problems of Enterprise Pension in China [D]. Shandong University of Finance and Economics, 2014.

[8] Huo Jinghong, Xu Richu. Study on the Pension System and Accounting Problems of Modern Social Enterprises under the Harmonious Background [J]. The World of Labor Security (theoretical edition), 2013, 12 (11): 11-12. 